\title{
Peningkatan Motivasi Belajar melalui Evaluasi E-Learning pada Institusi Keperawatan di Jakarta dan Depok
}

\author{
Sondang R. Sianturi ${ }^{1^{*}}$, Kristina Lisum ${ }^{2}$ \\ ${ }^{1,2}$ STIK Sint Carolus, Jakarta, Indonesia \\ *Email korespondensi: sondangrsianturi@gmail.com
}

\section{ARTICLE INFO \\ HOW TO CITED: \\ Sianturi, S.R., Lisum, K. (2018). Peningkatan Motivasi Belajar melalui Evaluasi E-Learning pada Institusi Keperawa- tan di Jakarta dan Depok. Jurnal Pendidi- kan Keperawatan Indo- nesia 4(2), hlm. 122-130}

DOI:

10.17509/jpki.v4i2.11563

\section{ARTICLE HISTORY: \\ Accepted \\ June 05, 2018}

Revised

December 06, 2018

Published

December 31, 2018

\section{A B S T R A K}

Pesatnya kemajuan teknologi mempengaruhi semua sector, termasuk sector pendidikan. Peran dosen sebagai fasilitator seharusnya dapat memfasilitasi mahasiswa untuk menemukan cara belajarnya masing masing. Dosen diharapkan dapat memfasilitasi mahasiswa supaya dapat belajar tanpa terbatas ruang dan waktu (dimana saja dan kapan saja). Diharapkan dengan metode pembelajaran e-learning maka mahasiswa menjadi lebih aktif dan semakin kreatif dalam belajar. Penelitian ini bertujuan untuk mengetahui apakah elearning memiliki pengaruh terhadap motivasi mahasiswa. Metode penelitian yang dilakukan adalah penelitian kuantitatif dengan desain penelitian kausal untuk menjelaskan hubungan sebab dan akibat dan menggunakan teknik purposive random sampling. Study ini menggunakan analisis Structural Equation Model (SEM) untuk melihat faktor mana yang paling berpengaruh dalam meningkatkan motivasi mahasiswa. Responden pada penelitian ini sejumlah 338 mahasiswa dengan alat pengumpul data berupa kuesioner baku e -learning (Watkins) yang telah ditranslasi dalam bahasa Indonesia. Mahasiswa yang menjadi responden sudah pernah melakukan elearning pada beberapa mata kuliah. Hasil dari penelitian ini menunjukkan bahwa penggunaan internet pada mahasiswa secara signifikan dapat mempengaruhi motivasi mahasiswa dalam menggunakan elearning ditunjukkan dengan tingkat significancy 8.31 (> dari 2) dengan tingkat keyakinan 95\% dan nilai R2 0.49 (error varians 0.75 ). Untuk itu, kompetensi mahasiswa yang ingin dicapai dapat didukung dengan pengembangan metode pembelajaran yang didukung dengan teknologi.

Kata kunci: e-learning; mahasiswa keperawatan; motivasi

\section{A B S T R A C T}

Technology is continue to progress more rapidly and it affect all sector in the world, including education. The lecturer's role as a facilitator should be able to facilitate the students to find their own way of learning. Lecturer need to facilitate students discovering their own way to learn without limited time and space (anytime and anywhere). E-learning will encourage students to learn more active and creative. The purpose of this study was to determine the influence of internet usaage with student's motivation and also factors that influence e-learning implementation. This study used descriptive method with causal design. Respondents in this study were 338 students with questionnaire from Watkins about e-learning which has been translated into Bahasa. Through Structural Equation Model (SEM) analyse that the internet usage on student can significantly influence student's motivation in using elearning shown with significancy level $8.31(>2)$ with $95 \%$ confidence level and value 
R2 0.49 (error vaeiance 0.75). The development of the pedagogical content by lecturer should be more creative in accordance with the technology used.

Key words: e-learning; nursing; motivation

\section{PENDAHULUAN}

Pesatnya kemajuan teknologi saat ini mempengaruhi semua sektor yang ada di Indonesia, termasuk dalam sektor pendidikan. Dalam sektor ini, teknologi telah mempengaruhi perubahan penyebaran konten dan informasi dari metode konvensional (tatap muka) menuju ke metode virtual. Sejak tahun 2008, UNESCO menyatakan bahwa lebih dari 455 juta penduduk di seluruh dunia menerima pendidikan dan pelatihan melalui internet. Mengiringi perubahan teknologi dan proses pembelajaran dimana mahasiswa dapat mencari, mengirim informasi melalui internet, maka kebutuhan akan pembelajaran berbasis elektronik dan internet semakin pesat.

Pembelajaran berpusat pada mahasiswa yang diusung saat ini tidak membatasi pembelajaran mahasiswa pada ruang dan waktu sehingga mahasiswa keperawatan nantinya tidak akan mengalami kesulitan untuk melakukan kreativitas dan inovasi dalam mengembangkan pengetahuan dan keterampilan keperawatan (Abdelhai, 2012). Hal ini dikemukakan oleh Renny (2012) bahwa sistem pembelajaran yang ada hendaknya harus memfasilitasi mahasiswa dan dosen dalam proses belajar mengajar. Hal ini pun dibuktikan dengan perkembangan teknologi yang ada di Jakarta seperti disediakannya areawifi bagi masyarakat yang dapat dimanfaatkan untuk mencari informasi seluas-luasnya.

Metode pembelajaran elearning ini sudah dilakukan di universitas luar negri dalam bentuk distance learning dimana mahasiswa tidak perlu tatap muka dengan dosennya. Di Indonesia, hal ini sudah dilakukan oleh pendidikan dalam bidang system informasi. Dari hasil pengamatan ada beberapa universitas yang sudah menggunakan elearning dalam proses pembelajarannya yaitu UGM (http://elisa.ugm.ac.id), UI (http://scele.ui.a.id), Unissula Semarang. ITB, Gunadarma, AMIKOM, UNPAR. Perubahan ini meluas sampai dengan bidang-bidang lain dalam pendidikan. Hal ini pun memberikan tantangan kepada pendidikan dalam bidang kesehatan. Perubahan tatanan pelayanan kesehatan termasuk keperawatan yang terjadi di Indonesia mendesak seluruh profesi kesehatan untuk mampu menciptakan lulusan yang mampu menjawab kebutuhan masyarakat saat ini dan dimasa yang akan datang. Strategi atau metode pembelajaran yang diciptakan oleh dosen harus menjawab kebutuhan tesebut dan tren terbaru dalam pendidikan tinggi yaitu membangun pembelajaran melalui elearning yang memberikan kemudahan bagi mahasiswa untuk mengakses konten perkuliahan (Irawati \& Putra, 2014).

Pelaksanaan elearning khususnya dalam bidang keperawatan merupakan suatu tantangan yang besar di Indonesia. Tantangan dalam bidang keperawatan yaitu mahasiswa keperawatan tidak hanya dituntut aspek kognitif saja melainkan juga skill dan afektif dimana mereka harus merawat manusia dengan beragam karakteristik. Pada metode pembelajaran elearning di keperawatan ini, ada hal yang tidak bias di penuhi oleh elektronik dan internet yaitu sense of care. Sedangkan pada era sekarang dan akan datang, teknologi memegang peranan yang sangat penting dalam semua aspek termasuk pendidikan. Oleh karena itu, jika dosen perawat tidak dapat mengikuti arus perkembangan teknologi informasi, maka selamanya akan terkungkung dari dunia luar seperti "katak dalam tempurung" Ketika mahasiswa diharapkan untuk berpartisipasi aktif dalam menemukan model pembelajarannya, dosen perawat pun diharapkan mampu "berlari" dan memfasilitasi mahasiswa dalam menemukan pembelajarannya. Mahasiswa pun merasa lebih enjoy dalam proses pembelajaran karena strategi dan metode yang dipakai sesuai dengan era yang ada. Mahasiswa menjadi lebih aktif dan creative dalam belajar dan mencari informasi terbaru. 
Dari hasil observasi dan wawancara dengan mahasiswa di keperawatan yang sudah melakukan e learning Mahasiswa keperawatan menyatakan bahwa mereka lebih menginginkan metode pembelajaran yang inovatif dan interaktif dan sesuai dengan perkembangan teknologi yang saat ini mereka hadapi. Fenomena tersebut menjadi tantangan tersendiri dalam dunia keperawatan untuk menciptakan lingkungan belajar yang menarik, interaktif dan tanpa batas. Lingkungan belajar yang inovatif dan interaktif dapat diperoleh dengan metode pembelajaran electronic learning. Pada e- learning, mahasiswa dituntut untuk proaktif dalam memperoleh pengetahuan dan ketrampilan yang diinginkan.

Mahasiswa secara tidak langsung diberikan motivasi untuk berusaha sekuat tenaga mendapatkan informasi dari berbagai sumber pembelajaran dengan panduan dan arahan dari dosen atau instruktur. Motivasi merupakan suatu dorongan yang diberikan dan yang timbul pada diri seseorang, dalam hal ini mahasiswa untuk melakukan kegiatan belajar guna mencapai prestasi belajar yang diinginkan (Sianturi, 2011). Dengan berbagai metode yang diberikan dalam proses pembelajaran, maka akan membuat mahasiswa bersemangat. Upaya yang dapat dilakukan untuk meningkatkan motivasi mahasiswa dalam belajar diantaranya adalah dengan memberikan semangat di kelas, memberikan harapan yang realistis, reward dan pujian pada mahasiswa yang berprestasi. Selain itu dukungan dari dosen sangat penting dalam menunjang motivasi belajar mahasiswa (Sianturi, 2011).

Pelaksanaan elearning yang baru dilaksanakan di bidang keperawatan ini perlu dilihat efektivitas pelaksanaannya baik dari sisi dosen dan mahasiswa. Oleh karena itu, peneliti ingin melakukan evaluasi pelaksanaan metode pembelajaran berbasis teknologi yaitu elearning pada mahasiswa di Fakultas ilmu Keperawatan di Jakarta dan Depok.

\section{METODE}

Penelitian ini menggunakan penelitian kuantitatif dengan disain penelitian kausal yang bertujuan untuk menjelaskan hubungan sebab dan akibat. Variabel sebab yaitu factor-faktor yang mempengaruhi penggunaan elearning ( usia, jenis kelamin, paparan terhadap internet, fasilitas internet, konten elearning) dan variable akibat yaitu motivasi belajar mahasiswa yang menggunakan metode e learning Populasi penelitian ini menggunakan infinite populasi (populasi tak terhingga) yaitu mahasiswa keperawatan yang ada di wilayah Jakarta dan Depok yang telah menggunakan metode elearning dalam proses pembelajaran. Metode elearning yang digunakan oleh peneliti yaitu metode pembelajaran dengan menggunakan elektronik dimana terdapat interaksi antara dosen dan mahasiswa di dalam system elearning (moodle atau schoology). Responden pada penelitian ini adalah berjumlah 338 mahasiswa yang dilakukan pada 3 institusi keperawatan di Jakarta, dan 1 institutsi keperawatan di Depok. Peneliti menggunakan kuesioner baku Watkins mengenai e-learning yang telah ditranlasi dalam bahasa Indonesia. Data diolah menggunakan konfirmatory dengan perangkat Lisrel dengan menggunakan Struktural Equation Model (SEM).

\section{HASIL DAN PEMBAHASAN}

Jumlah responden penelitian adalah 338 mahasiswa keperawatan. Data demografi responden ditulis pada table dibawah. Sebagian besar jenis kelamin responden adalah perempuan sebanyak $89,1 \%$, yang berusia sekitar $19-22$ tahun dan sebanyak $94.4 \%$ responden sedang menjalani perkuliahan di program studi S1 Keperawatan. Selain data demografi, juga disajikan data mengenai factor yang mempengaruhi penggunaan elarning sebagai salah satu metode pembelajaran. Sebagian besar mahasiswa sebanyak 89,3 \% sudah pernah mendapat pelatihan mengenai metode pembelajaran elearning, terpapar internet rata-rata $3-5$ jam sebanyak $52.4 \%$. Hal ini dapat memudahkan dosen untuk melakukan proses pembelajaran jika mahasiswa memiliki paparan waktu yang cukup terhadap akses internet. Sebagian mahasiswa menggunakan fasilitas yang tersedia di kampus berupa Wifi dan modem pribadi masing masing sebanyak $50 \%$. Selain itu juga didapat data 
bahwa masing-masing mahasiswa menyatakan bahwa kampus telah mengembangkan elearning dengan baik yang ditunjukkan dengan kombinasi dalam penggunaan e learning yaitu minimal 3 konten sebanyak $73.4 \%$.

Tabel 1 menggambarkan data demografi responden dimana sebagian besar responden yaitu Perempuan (89.1\%) yang berusia 19-21 tahun.
Tabel 2 menggambarkan hasil data univariat mengenai faktor-faktor yang mempengaruhi penggunaan elearning yaitu faktor internal (usia, jenis kelamin dan paparan terhadap digital) dan factor eksternal yaitu fasilitas yang digunakan dan konten e learning.

Tabel 1. Karakteristik Responden

\begin{tabular}{clr}
\hline $\begin{array}{c}\text { Jenis kelamin } \\
\text { Laki laki } \\
\text { Perempuan }\end{array}$ & 37 & $10.9 \%$ \\
Usia & 301 & $89.1 \%$ \\
18 tahun & 11 & $3.3 \%$ \\
19 tahun & 61 & $18.0 \%$ \\
20 tahun & 145 & $42.9 \%$ \\
21 tahun & 58 & $17.2 \%$ \\
22 tahun & 24 & $7.1 \%$ \\
\hline Pendidikan & 319 & \\
S1 Keperawatan & 19 & $54.4 \%$ \\
S2 Keperawatan & & $5.6 \%$ \\
\hline
\end{tabular}

Tabel 2. Faktor yang mempengaruhi penggunaan e learning

\begin{tabular}{lcc}
\hline Pelatihan e-learning sebelumnya & 302 & $89.3 \%$ \\
Pernah & 33 & $9.8 \%$ \\
Belum & 18 & $5.3 \%$ \\
\hline Jumlah mata kuliah yang dilakukan e-learning & $8.3 \%$ \\
1 & 28 & $2.1 \%$ \\
2 & 7 & $84 \%$ \\
3 & 284 & \\
$>4$ & & $26.3 \%$ \\
Konten yang digunakan pada e-learning & 89 & $24.9 \%$ \\
$1-2$ & 84 & $48.5 \%$ \\
$3-4$ & 164 & $13.6 \%$ \\
$5-6$ & & $52.4 \%$ \\
Lama terpapar dengan computer & 46 & $33.7 \%$ \\
2 jam & 177 & \\
$3-5$ jam & 114 & $91.1 \%$ \\
$>6$ jam & & $8.6 \%$ \\
\hline Kemudahan fasilitas internet & 308 & \\
Ya & 29 & $4.1 \%$ \\
Tidak & & $50 \%$ \\
\hline Fasilitas yang digunakan & 14 & $44.7 \%$ \\
Tidak ada & 169 & \\
$>1$ fasilitas & 151 & \\
\hline
\end{tabular}


Dari hasil analisa bivariat didapatkan hubungan yang bermakna antara usia dan fasilitas terhadap penggunaan elearning dengan nilai $\mathrm{p}$ value masing masing sebesar 0,008 dan 0,000 (p value $<0.05)$. Analisis yang digunakan pada hubungan fasilitas terhadap penggunaan e learning ini yaitu analisis chi square dengan $\mathrm{P}$ value 0,000 .

Analisis yang digunakan pada hubungan paparan terhadap internet dan konten yang menggunakan elearning terhadap penggunaan internet yaitu dengan analisis Kendall's tau_b dengan $P$ value 0,713 dan $P$ value untuk analisis konten terhadap penggunaan internet yaitu 0,737 dimana tidak ada hubungan yang significant antara berapa lama terpapar internet dan konten yang diberikan oleh dosen karena dosen hanya mengirimkan materi saja dalam bentuk ppt atau pdf.

Perkembangan ilmu pengetahuan teknologi menuntut terjadinya globalisasi pembelajaran sehingga dibutuhkan kecepatan terhadap akses untuk mendapatkan sumber pengetahuan khususnya pada usia remaja akhir atau dewasa awal. Dari hasil diatas disebutkan bahwa usia berhubungan secara signifikan dengan penggunaan internet dengan nilai $\mathrm{p}$ value 0.0008 ( $\mathrm{p}$ value $<0.005$ ). Mahasiswa saat ini berada pada kehidupan serba teknologi sehingga mereka selalu berhadapan dengan teknologi dan internet. Hal ini senada dengan penelitian yang dilakukan oleh Khadmlu, et al, 2013 yang menyatakan bahwa terjadi hubungan yang signifikan antara usia dengan penggunaan e-

Tabel 3. Hubungan fasilitas dengan penggunaan internet

\begin{tabular}{lccc}
\hline & Value & Df & Asymptotic Significance (2-sided) \\
\hline Pearson Chi-Square & $507,656^{\mathrm{a}}$ & 232 &, 000 \\
Likelihood Ratio & 130,294 & 232 & 1,000 \\
Linear-by-Linear Association & 12,194 & 1 &, 000 \\
Likelihood Ratio & & & \\
N of Valid Cases & 338 & & \\
\hline
\end{tabular}

a. 335 cells $(95.4 \%)$ have expected count less than 5 . The minimum expected count is .00 .

Tabel 4. Hubungan paparan terhadap internet dan konten yang menggunakan elearning terhadap penggunaan internet.

\begin{tabular}{|c|c|c|c|c|c|}
\hline & & & $\begin{array}{l}\text { lama- } \\
\text { terpapar }\end{array}$ & konten & piratarata \\
\hline \multirow[t]{9}{*}{$\begin{array}{l}\text { Kendall's } \\
\text { tau_b }\end{array}$} & \multirow[t]{3}{*}{ Lama terpapar } & $\begin{array}{l}\text { Correlation Co- } \\
\text { efficient }\end{array}$ & 1,000 &, $413^{* *}$ &,- 016 \\
\hline & & Sig. (2-tailed) & & ,000 & ,713 \\
\hline & & $\mathrm{N}$ & 338 & 338 & 338 \\
\hline & \multirow[t]{3}{*}{ konten } & $\begin{array}{l}\text { Correlation Co- } \\
\text { efficient }\end{array}$ &, $413^{* *}$ & 1,000 &,- 014 \\
\hline & & Sig. (2-tailed) & ,000 & & ,737 \\
\hline & & $\mathrm{N}$ & 338 & 338 & 338 \\
\hline & \multirow[t]{3}{*}{ piratarata } & $\begin{array}{l}\text { Correlation Co- } \\
\text { efficient }\end{array}$ &,- 016 &,- 014 & 1,000 \\
\hline & & Sig. (2-tailed) &, 713 & ,737 & . \\
\hline & & $\mathrm{N}$ & 338 & 338 & 338 \\
\hline
\end{tabular}

**. Correlation is significant at the 0.01 level (2-tailed). 
learning sebagai metode pembelajaran. Penelitian ini dilakukan terhadap mahasiswa kedokteran dan Farmasi di Iran. Variasi dalam metode pembelajaran dengan menggunakan elearning ini ternyata bagi kalangan mahasiswa pada saat ini dirasakan mampu menjawab kebutuhan mahasiswa sehingga proses pembelajaran menjadi lebih menarik.

Fasilitas yang dimiliki oleh suatu perguruan tinggi sangat berperan dalam proses pendidikan dan pembentukan pengetahuan termasuk diantaranya adalah computer, internet/wifi yang digunakan oleh mahasiswa. Dari hasil diatas, didapatkan hubungan yang signifikan antara fasilitas perguruan tinggi berupa computer beserta dengan internet/wifi dengan penggunaan internet dengan nilai $\mathrm{P}$ value 0.000 (pvalue < $0.05)$.

Paradigma student centered learning telah menggiring cara mahasiswa untuk menemukan pembelajarannya sendiri. Dengan demikian, sangatlah penting bagi suatu institusi perguruan tinggi untuk menyediakan fasilitas untuk menunjang proses pendidikan, terutama computer, kemudahan mengakses internet. Dalam penelitian yang dilakukan oleh Esmat, N., Abbas.A., Maddah Sadat, S.B., 2013 menyebutkan bahwa terdapat hubungan yang signifikan antara penggunaan sumber elektronik dengan metode pembelajaran pada mahasiswa keperawatan di Iran dengan nilai $\mathrm{p}$ value $<0.0001$.
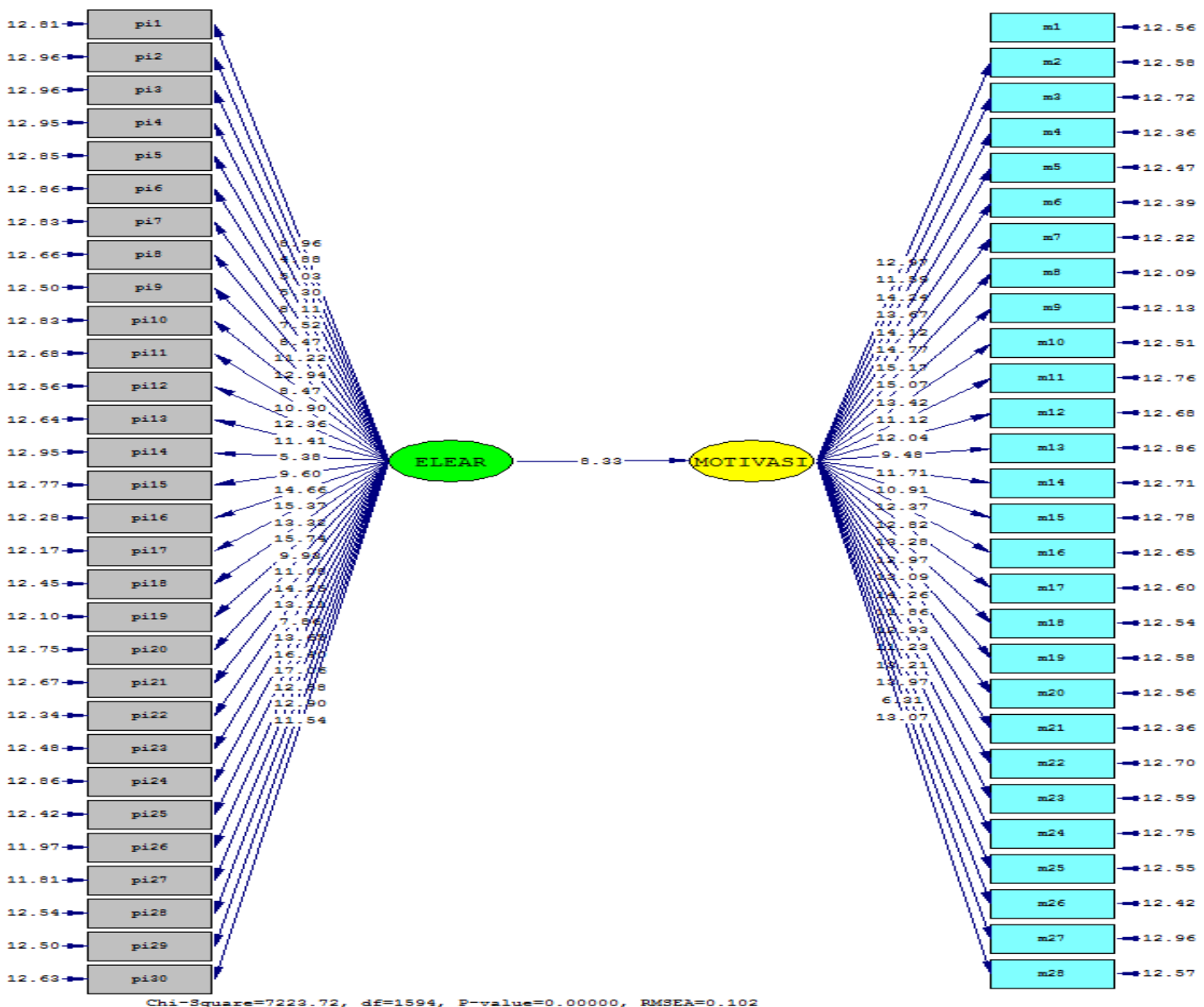

Gambar 1. Hubungan Penggunaan elearning terhadap Motivasi Belajar mahasiswa yang menggunakan elearning 
Kemudahan akses yang dimiliki oleh suatu perguruan tinggi sangat dibutuhkan oleh mahasiswa. Ketika mahasiswa dapat mengaksws internet dengan mudah, maka mahasiswa akan dapat bereksplorasi dengan pengetahuan, atau bahkan dapat berkreasi melalui internet. Hal ini ditunjukkan dengan hasil penelitian diatas bahwa tidak ada hubungan yang signifikan antara lama terpapar internet dan banyaknya konten dalam menggunakakan e-learning dengan penggunaan internet pada mahasiswa dengan nilai $\mathrm{p}$ value 0.713 dan 0.737 ( $\mathrm{P}$ value $>0.005$ ).

Analisis Multivariate dilakukan dengan menggunakan model persamaan struktural (Struktural Equation Modelling/SEM) dimana salah satu motode multivariate yang memungkinkan peneliti untuk menguji hubungan antara variabel penggunaan e learning

Analisis Multivariate dilakukan dengan menggunakan model persamaan struktural (Struktural Equation Modelling/SEM) dimana salah satu motode multivariate yang memungkinkan peneliti untuk menguji hubungan antara variabel penggunaan elearning terhadap motivasi belajar mahasiswa yang menggunakan e learning.

Pada gambar 1, hasil analisis menggunakan SEM digunakan untuk melihat pengaruh dari penggunaan elearning dengan motivasi belajar mahasiswa yang menggunakan elearning. Berdasarkan output Gambar 1 diperoleh bahwa motivasi mahasiswa pada saat menggunakan elearning adalah cukup tinggi dengan nilai kuesioner tidak ada yang bernilai rendah. Dari hasil tersebut, maka degree of freedom yang dihasilkan adalah 4.5, sehingga model diatas dapat diidentifikasi estimasinya.

Berdasarkan hasil analisis dapat diketahui bahwa penggunaan elearning pada mahasiswa mempengaruhi motivasi mahasiswa dalam menggunakan elearning ditunjukkan dengan tingkat significancy 8.31 (>dari 2) dengan tingkat keyakinan $95 \%$. Sedangkan nilai $\mathrm{R}^{2}$ atau nilai kontribusi penggunaan internet terhadap motivasi 0.49 dengan nilai error varians 0.75 . Untuk pengujian model hubungan antar variable (analisis path yaitu pada gambar 3) yaitu model ini dianalisis dengan Root Mean Square Error of
Approximation (RMSEA) untuk mendapat nilai P-Value for Test of Close Fit yaitu 0.00 (RSMEA < 0.05). Hal ini menunjukkan bahwa model ini valid atau fit dan dapat bermanfaat untuk prediksi. Hal ini menunjukkan bahwa responden memiliki kekuatan untuk mencapai tujuan yang pasti selama menjalankan kewajibannya sebagai mahasiswa. Karena ketika mahasiswa tidak memiliki motivasi dalam belajar, maka ia tidak adan melakukan aktivitas belajarnya dan tidak memiliki keinginan untuk menguasai ilmu pengetahuan dan teknologi.

Proses belajar mahasiswa dengan menggunakan elektronik menimbulkan sikap aktif dan kreatif. Belajar secara aktif mempunyai banyak keuntungan karena dapat dipelajari beberapa keterampilan sekaligus seperti keterampilan bekerja dalam tim, memformulasikan masalah, menemukan informasi, dan membuat keputusan (Nursalam \& Fery Efendy, 2008). Proses pembelajaran dengan menggunakan teknologi seperti Elearning ini memungkinkan mahasiswa belajar melalui computer di tempat masingmasing tanpa harus hadir secara fisik di kampus. Selain itu juga merupakan pembelajaran berbasis web dimana menggunakan akses internet (secara online).

E learning merupakan suatu sistem/konsep pendidikan yang memanfaatkan teknologi informasi dalam proses belajar mengajar tanpa harus bertatap muka secara langsung antara dosen dan mahasiswa (Michael,2013; Chandrawati,2010; Ardiansyah, 2013). Metode pembelajaran elearning ini memiliki beberapa manfaat yang positif yaitu fleksibel artinya dosen dan mahasiswa dapat memilih waktu dan tempat untuk mengakses, belajar mandiri artinya dengan elearning mahasiswa dapat menentukan sendiri kapan dan apa yang dibutuhkan serta dapat mengeksplorasi ilmu yang dimiliki, bahan belajar tak terbatas. Hal ini dikuatkan oleh penelitian Sianturi (2017) yang menjelaskan keuntungan menggunakan metode pembelajaran elearning yaitu dapat menghemat waktu proses belajar mengajar, mengurangi biaya perjalanan, menghemat biaya buku-buku, dan melatih mahasiswa menjadi lebih aktif dan kreatif. 
Mahasiswa yang menjadi responden pada penelitian ini merupakan mahasiswa yang hidup pada jaman milenial (table 3) dimana sudah banyak terpapar dengan teknologi informasi. Hal ini menjadi tantangan bagi dosen untuk memodifikasi proses pembelajaran sesuai dengan gaya dan perkembangan teknologi yang dihadapi oleh mahasiswa. Dengan perannya sebagai fasilitator, maka dosen dituntut untuk memodifikasi metode pembelajaran menjadi lebih interaktif dan menggunakan virtual yang lebih atraktif untuk meningkatkan motivasi mahasiswa. Kualitas pembelajaran dapat dilihat dari motivasi mahasiswa yang dapat berdampak pada kepuasan belajar menjadi lebih tinggi. Bila mahasiswa sudah dapat mengidentifikasi cara belajar mereka sendiri, maka hal itu akan menjadi salah satu kekuatan dalam menentukan prestasi mahasiswa di institusi perguruan tinggi.

\section{SIMPULAN DAN SARAN}

Metode pembelajaran dengan menggunakan elektronik atau disebut dengan elearning merupakan metode pembelajaran yang membutuhkan variasi dan kesiapan dari banyak pihak. Metode elearning perlu dipersiapkan sebelum memulai perkuliahan mengenai desain pembelajaran, material, dan bentuk dari diksusi dan tugas yang diberikan pada mahasiswa. Dengan begitu akan tercipta kualitas mahasiswa yang sesuai dengan kompetensi yang diharapkan oleh dosen dan institusi.

\section{REFERENSI}

Abdelhai, R., Yassin, S., Ahmad, M., \& Fors, U. (2012). An elearning reproductive health module to support improved student learning and interaction: Aprospective interventional study at a medical school in Egypt. BMC Medical Education, 1-9.

Ali, Wafaa Gameel M. (2012). Factors affecting nursing student's satisfaction with elearning experience in King Khalid University, Saudi Arabia. International Journal of Learning and Development, 201-214.

Ardiansyah, Ivan. (2013). Eksplorasi Pola Komunikasi dalam Diskusi menggunakan
Kualitas penyelenggaraan pembelajaran elearning ini tidak diperngaruhi oleh waktu paparan mahasiswa terhadap internet, konten yang diberikan pada saat pembelajaran elearning dan fasilitas yang digunakan oleh mahasiswa seperti computer dan internet yang dapat menunjang mahasiswa melakukan elearning. Hal ini disesuaikan dengan gaya belajar mahasiswa pada generasi milenial, sehingga proses pembelajaran menjadi lebih dinamis. Mahasiswa dapat terdorong untuk selalu belajar dan selalu mencari tahu tentang kesehatan. Dengan begitu motivasi mahasiswa untuk belajar menjadi lebih tinggi dan pada akhirnya akan mempengaruhi prestasi belajar mahasiswa. Dosen sebagai fasilitator bertanggung jawab untuk memfasilitasi gaya belajar dengan menggunakan metode pembelajaran yang sesuai. Dengan demikian proses belajar mengajar menjadi lebih efektif.

\section{UCAPAN TERIMAKASIH}

Peneliti mengucapkan terimakasih kepada Direktorat Pendidikan Tinggi yang telah memberikan kesempatan peneliti untuk mendapatkan Hibah Penelitian Dosen Pemula dan STIK Sint Carolus yang telah mendukung peneliti dalam melakukan penelitian. Selain itu juga peneliti mengucapkan terimakasih kepada Universitas Indonesia, Universitas Esa Unggul, STIKES Binawan sebagai tempat penelitian.

Moddle pada perkuliahan Simulasi Pembelajaran Kimia. Bandung: Universitas Pendidikan Indonesia

Chandrawati, Sri Rahayu. (2010). Pemanfaatan elearning dalam Pembelajaran. Jurnal Untan: No.2 Vol 8.

Irawati, Anik \& Putra, Dedi. (2014). Analisis Technology Acceptance Model dalam Memahami Niat Perilaku Mahasiswa untuk menggunakan Elearning. Prosiding Seminar Bisnis dan Teknologi. ISSN:2407-6171.

Metin, M., Yilmaz, G. K., Coskun, K., \& Birisci, S. (2012). Developing an Attitude Scale Towards using Instructional Technologies 
for Service Teachers. The Turkish Online Journal of Educational Technology, 36-45.

Michael, Allen. (2013). Michael Allen's Guide to E-learning. Canada: John Wiley \& Sons.

Renny, Wulan. (2012). Penerapan hybrid elearning dalam pendidikan keperawatan. Mahasiswa Pasca Sarjana Keperawatan Medikal Bedah UI. Jakarta

Rosen, L., Whaling, K., Carrier, L., Cheever, N., \& Rokkum, J. (2013). The Media and Technology Usage and Attitudes Scale: An empirical investigation. Computers in $\mathrm{Hu}$ man Behavior , 2501- 2511.

Sianturi, SR. (2017). Informatics technology in the Classroom. Nursing Care Open Access Journal. Medcrave

Swanwick, T. (2010). Understanding medical education : Evidence, theory and practice. London: Wiley-Blackwell.

Tezci, E. (2010). Attitudes and Knowledge level of Teachers in ICT use: The case of Turkish teachers. International Journal of Human Sciences , 19-44.
Franki, G \& Bitter, S. (2011). Student perscpective on elearning in a Blended learning context. Klagenfurt, Austria, 79-88.

Istrate, Olimpius. (2012). Criteria for elearning programs evaluation. The 8th International $S$ ientific Conference eleanring and software for education, Budhapest.

Boeker, Andel, Vach \& Frankenschmidt. (2013). Game-Based Elearning is more effective than a conventional instructional method: A randomized controlled trial with third-year medical students. PLOS ONE, vol 8, p1-11

Zaid, Al-Shammari. (2011). Does Integrating technology-based attendance into teacher education program improve student achievement in Kuwait? College Student Journal, pg. 839

Wahl, Stacy. (2011). Nursing education innovation: using elearning technology to meet learners' needs. The journal of continuing education in nursing: vol 42, p. 483-484 